\title{
Mechanism of efficient nutrient removal and microbial analysis of a combined anaerobic baffled reactor-membrane bioreactor process
}

\author{
P. Wu $\cdot$ X. Ji $\cdot$ X. Song $\cdot$ Y. Shen
}

Received: 13 January 2013/Revised: 7 May 2013/Accepted: 26 May 2013/Published online: 14 June 2013

(C) Islamic Azad University (IAU) 2013

\begin{abstract}
A combined ABR-MBR process consisting of an anaerobic baffled reactor (ABR) combined with an aerobic membrane bioreactor (MBR) treating municipal wastewater was investigated at controlled $\mathrm{pH}$ range 6.5-8.5 and at constant temperature $25 \pm 1{ }^{\circ} \mathrm{C}$. Total nitrogen $(\mathrm{TN})$, ammonia $\left(\mathrm{NH}_{4}{ }^{+}-\mathrm{N}\right)$, total phosphorus (TP), and chemical oxygen demand (COD) removal performances were evaluated by analyzing the mechanism for efficient nutrient removal. The results showed that the average removal rates of COD, $\mathrm{NH}_{4}{ }^{+}-\mathrm{N}, \mathrm{TN}$, and TP reached 93, 99,79 , and $92 \%$, respectively, corresponding with the COD, $\mathrm{NH}_{4}{ }^{+}-\mathrm{N}, \mathrm{TN}$, and TP effluent of $24(18-31), 0.4$ $(0-0.8), 10.6(8.8-12.9)$, and $0.31(0.1-0.5) \mathrm{mg} / \mathrm{L}$ under the operational condition of hydraulic retention time (HRT) $7.5 \mathrm{~h}$, recycle ratio $200 \%$, and dissolved oxygen $3 \mathrm{mg} / \mathrm{L}$. The MBR enhanced $\mathrm{NH}_{4}{ }^{+}-\mathrm{N}$, TN, and TP removal rates of 13,10 , and $18 \%$, respectively, and the membrane retention reduced TP $0.17 \mathrm{mg} / \mathrm{L}$. The process was able to maintain a stable performance with high-quality effluent. Analysis of the results by fluorescence in situ hybridization showed that the abundance of ammonia-oxidizing bacteria, nitriteoxidizing bacteria, and phosphorus accumulating organisms as percentages of all bacteria in each compartment was stable. The enriched microorganisms in the system appear to be the main drivers of the process efficient for nutrient removal.
\end{abstract}

P. Wu $\cdot$ Y. Shen $(\bowtie)$

School of Environmental and Civil Engineering,

Jiangnan University, Wuxi 214122, China

e-mail: wupengniu@126.com

X. Ji $\cdot$ X. Song $\cdot$ Y. Shen

Key Lab of Environmental Science and Engineering of Jiangsu

Province, Suzhou University of Science and Technology,

Suzhou 215011, China
Keywords Anaerobic processes - Aerobic processes . Membrane bioreactors · Optimization · Municipal wastewater $\cdot$ Nutrient removal

\section{Introduction}

Nutrient enrichment could lead to the outbreak of nuisance, toxic cyanobacterial blooms and decreases the quality of water used for drinking, industrial, agricultural, recreational, and other purposes (Chuai et al. 2012; Hong et al. 2012). Biological nutrient removal is an important aspect of municipal wastewater treatment and reuse processes $(\mathrm{Su}$ et al. 2011; Strosnider et al. 2011; Monclús et al. 2010). However, it is a very complicated process, including nitrification, denitrification, anaerobic phosphorus release, aerobic phosphorus uptake, and other processes. Biological nutrient removal needs a large number of co-proprietary microorganisms to complete in suitable environmental conditions. Because nitrifying bacteria are sensitive to environmental change and grow slowly, nitrification becomes the restrictive step in biological treatment processes (Satoshi et al. 1999). However, membrane bioreactor (MBR) is considered as an important means of solving the problem of insufficient nitrification in traditional processes and can retain activated sludge due to efficient retention, preventing the loss of organisms (Suwa et al. 1992; Yamagishi et al. 2001).

In recent decades, considerable studies and efforts to improve the water quality have been conducted since algal blooms in Taihu lake began to occur much more frequently due to the large amounts of nutrients discharged into rivers and transported to the lake (Tian et al. 2012). In this regard, the MBR was used as a post-processing reactor to treat the anaerobic baffled reactor (ABR) effluent on municipal 
wastewater treatment. Because the MBR has high retention efficiency of microorganisms such as ammonia-oxidizing bacteria, nitrite-oxidizing bacteria, nitrification under aerobic conditions can be fully achieved. Denitrification can be completed in the first compartment of the ABR by recycling the nitrification liquor in that compartment. Total phosphorus concentration increased to maximum in the second compartment of the ABR as a result of P-release by recycled phosphorus accumulating organisms and then decreased in the anoxic zones due to the dilution by the recycling stream and P-uptake by the denitrifying polyphosphate accumulating organisms in the third compartment of the ABR. Subsequently, phosphorus was further taken up by phosphorus accumulating organisms, and complete biological phosphorus removal was achieved in the aerobic zones. Therefore, phases of nitrification, denitrification, phosphorus uptake, and phosphorus release were separated in different compartments of the combined ABR-MBR process (CAMBR), while the large size granular sludge at the bottom of each compartment did not participate in sludge recycling, which further stabilized the original function of the compartment. Finally, nutrient removal was strengthened through sludge discharge. The objectives of the study were (1) to determine $\mathrm{COD}, \mathrm{NH}_{4}{ }^{+}-\mathrm{N}, \mathrm{NO}_{3}{ }^{-}-\mathrm{N}, \mathrm{NO}_{2}{ }^{-}-\mathrm{N}$, $\mathrm{TN}$, and TP in each compartment to analyze the mechanism of nutrient removal in the CAMBR, (2) to relate percentages of the community composition to treatment process performance, and (3) to assess the similarity of the bacterial communities in each compartment of the CAMBR. The study was done at the key laboratory of environmental science and engineering of Jiangsu province in Suzhou of China from March 2012 to July 2012.

\section{Materials and methods}

\section{Synthetic wastewater}

The selected synthetic wastewater was based on the characteristics of the municipal wastewater in the Suzhou wastewater treatment plant (Suzhou, China). The composition of the wastewater from a WWTP (Suzhou, China) was as follows $(\mathrm{mg} / \mathrm{L}): \mathrm{COD}, 366 \pm 77 ; \mathrm{NH}_{4}{ }^{+}-\mathrm{N}$, $32 \pm 12$; TN, $44 \pm 16$; TP, $4 \pm 3$; and suspended solids (SS), $277 \pm 151$. The reactor feed contained glucose, ammonium chloride, dipotassium hydrogen phosphate, and potassium dihydrogen phosphate, which were used as the primary organic, nitrogenous, and phosphorous components. A solution of the trace elements solution $\mathrm{H}_{3} \mathrm{BO}_{3}$ $50 \mathrm{mg}, \mathrm{CuCl}_{2} 30 \mathrm{mg}\left(\mathrm{NH}_{4}\right)_{6} \mathrm{Mo}_{7} \mathrm{O}_{24} \cdot 4 \mathrm{H}_{2} \mathrm{O} 50 \mathrm{mg}, \mathrm{ZnCl}_{2}$ $50 \mathrm{mg}, \mathrm{NiCl}_{2} \cdot 6 \mathrm{H}_{2} \mathrm{O} 50 \mathrm{mg}, \mathrm{CoCl}_{2} \cdot 6 \mathrm{H}_{2} \mathrm{O} 50 \mathrm{mg}$, Na$\mathrm{SeO}_{4} \cdot 10 \mathrm{H}_{2} \mathrm{O} 100 \mathrm{mg}, \mathrm{MnSO}_{4} \cdot \mathrm{H}_{2} \mathrm{O} 500 \mathrm{mg}$, and EDTA $1,000 \mathrm{mg}$ per liter was added to sustain the microbial growth (Chu et al. 2006; Gong et al. 2008). Raw wastewater from a campus housing facility's sewer line was pumped into a storage tank for sedimentation and then mixed into the synthetic wastewater. The composition of the raw wastewater was as follows $(\mathrm{mg} / \mathrm{L})$ : COD, $210 \pm 114 ; \mathrm{NH}_{4}{ }^{+}-\mathrm{N}, 16.7 \pm 9.3 ; \mathrm{TN}, 26.3 \pm 20.5 ; \mathrm{TP}$, $2.1 \pm 2.0$; and SS, $154.1 \pm 90.6$. The influent was a mix of raw and synthetic wastewater $(1: 1)$ with an average COD concentration of approximately $400 \mathrm{mg} / \mathrm{L}$ and ammoniumnitrogen concentration of $35 \mathrm{mg} / \mathrm{L}$, total nitrogen concentration of $50 \mathrm{mg} / \mathrm{L}$, and TP concentration of $4 \mathrm{mg} / \mathrm{L}$.

\section{CAMBR configuration}

The CAMBR configuration used is shown in Fig. 1. The reactor was made of perspex with a total effective volume of $15 \mathrm{~L}$. It consisted of three parts: an ABR with 3 compartments, an aerobic tank, and an MBR tank. The ABR was inoculated with anaerobic sludge which had a mixed liquor suspended solids (MLSS) concentration about $22 \mathrm{~g} / \mathrm{L}$, mixed liquor volatile suspended solids (MLVSS) concentration about $10 \mathrm{~g} / \mathrm{L}$. The aerobic tank and the MBR tank were inoculated with aerobic sludge which had a MLSS concentration about $5 \mathrm{~g} / \mathrm{L}$, MLVSS concentration about $2 \mathrm{~g} / \mathrm{L}$. Both two kinds of seed sludge were collected from the municipal wastewater treatment plant (Suzhou, China). The sludge retention time (SRT) was controlled at 15-20 days by sludge wastage. The sludge production yield versus organic loading rates were varied from 0.21 to $0.38 \mathrm{~kg} \mathrm{MLSS} / \mathrm{kg}$ COD after day 90. It was consistent with the results of Uan et al. (2013). While the operation of the CAMBR was stable, the MLSS in the MBR tank was kept around $8 \mathrm{~g} / \mathrm{L}$. The temperature of the reactor was maintained at $25 \pm 1{ }^{\circ} \mathrm{C}$. A hollow fiber membrane module (PVDF, hydrophilic, pore size: $0.1 \mu \mathrm{m}$, area of membrane: $0.15 \mathrm{~m}^{2}$ ) was immersed in the MBR. For all operations, the MBR mixed liquor, with a recycle ratio of $200 \%$, was introduced to the first compartment of the ABR, while the MBR mixed liquor, kept at a constant flow rate of $50 \%$ influent, was introduced to the third compartment of the ABR. A peristaltic pump was connected to the membrane module. The suction pump was operated in a timing sequence consisting of 10-min switched on and 2-min backwashing.

\section{Experimental approach}

This experiment consisted of two approaches. For the first approach, the CAMBR was operated before day 90 with a hydraulic retention time (HRT) of $10 \mathrm{~h}$ at a recycle ratio of $200 \%$ and dissolved oxygen (DO) at $3 \mathrm{mg} / \mathrm{L}$. For the second approach, the mechanism of nutrient removal in the CAMBR was investigated with HRT of $7.5 \mathrm{~h}$ at recycle ratio of $200 \%$ as DO of $3 \mathrm{mg} / \mathrm{L}$ during day 90 to day 102 . 


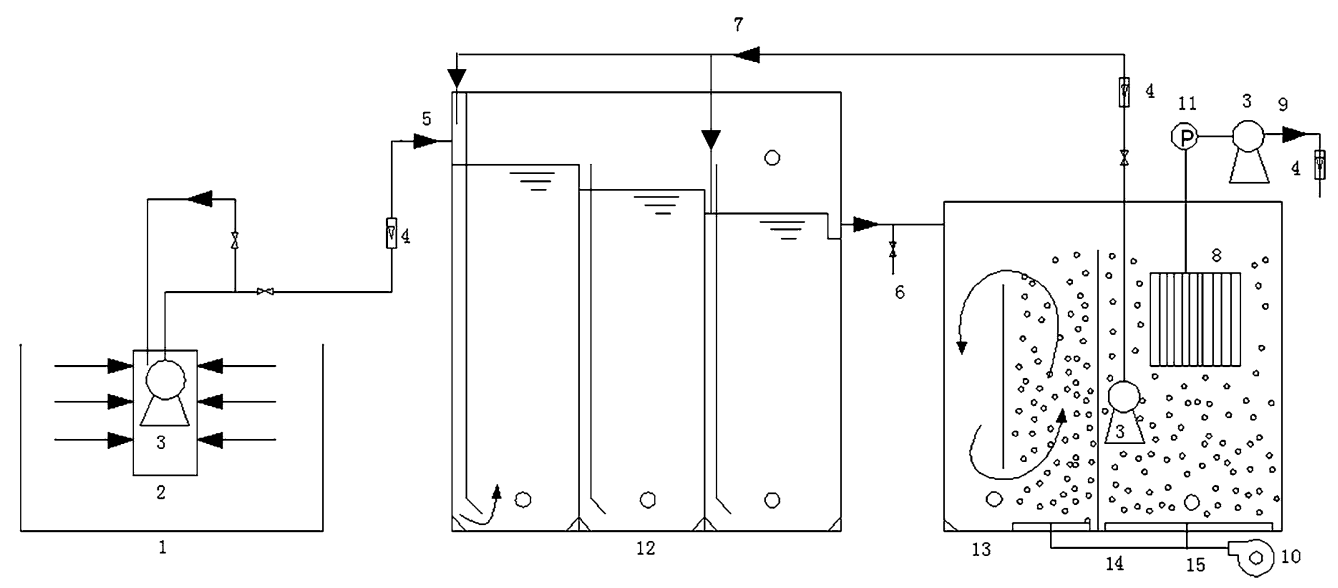

Fig. 1 Schematic diagram of the experimental CAMBR. 1 Feed tank; 2 screen; 3 pump; 4 flow meter; 5 influent; 6 ABR effluent; 7 recycle; 8 membrane model; 9 effluent; 10 air pump; 11 pressure meter; 12 ABR; 13 aerobic tank; 14 air diffuser; 15 MBR tank

In the MBR tank, phosphorus was removed by means of the biological uptake of phosphorus by the activated sludge bacteria (Kim et al. 2010; Peng and Ge 2011). In this study, a steady-state condition was considered to be reached when the variation of the measurements was less than $10 \%$. The average values of the data obtained under steady-state condition were used for further calculations.

\section{Chemical analysis}

The samples from each compartment were membrane filtered $(0.45 \mu \mathrm{m})$ before analysis. $\mathrm{COD}, \mathrm{NH}_{4}{ }^{+}-\mathrm{N}, \mathrm{NO}_{2}{ }^{-}-\mathrm{N}$, $\mathrm{NO}_{3}{ }^{-}-\mathrm{N}, \mathrm{TN}$, and TP concentration were measured regularly according to standard methods, as set out by the American Public Health Association/American Water Works Association/Water Environment Federation (APHAAWWA-WEF 2005). DO was continuously monitored by WTW, pH/oxi340i meter with DO probes (WTW Company, Germany). The $\mathrm{pH}$ and temperature were measured online by using WTW level $2 \mathrm{pH}$ meters (WTW Company, Germany).

\section{Statistical analysis}

$T$-test was performed using Microsoft Excel 2007, and significance level $(p)$ was determined.

Fluorescence in situ hybridization analysis

For in situ hybridization, the samples were taken from each compartment and treated as described by Röske et al. (1998). All in situ hybridizations were performed according to the standard hybridization protocol (Amann 1995). All oligonucleotide probes were obtained from TaKaRa (Dalian, China): The domain-specific EUB338 labeled with the fluorescence dye $\mathrm{Cy} 3$, and other oligonucleotide probes labeled with fluorescein isothiocyanate (FITC). After hybridization, the slides were rinsed with distilled water and air-dried. Finally, the slides were immediately analyzed under a fluorescence microscope (Nikon Microphoto-SA, Japan). The information of oligonucleotide probes [EUB338 (5'-GCTGCCTCCCGTA GGAGT-3'), Non 338 ( $5^{\prime}$-ACTCCTACGGGAGGCAGC- $\left.3^{\prime}\right)$, Nso190 (5'-CGATCCCTGCTTTTCTCC-3'), Nit3 (5'-CCTG TGCTCCATGCTCCG-3'), CNit3 (5'-CCTGTGCTCCAGG CTCCG- $\left.3^{\prime}\right)$ and PAOMIX (PAO462 (5'-CCGTCATCTAC WCAGGGTATTAAC- $\left.3^{\prime}\right)$, PAO65 1 (5'-CCCTCTGCCAA ACTCCAG-3'), PAO846 (5'-GTTAGCTACGGCACTAA AAGG-3 $\left.{ }^{\prime}\right)$ ] along with different concentration of $\mathrm{NaCl}$ and formamide correspondingly referred to Crocetti, Egli, and Coskuner's work (Crocetti et al. 2000; Egli et al. 2003; Coskuner et al. 2005). Microscopy was performed using an epifluorescence microscope (OlympusCX41, Japan) together with the standard software package delivered with the instrument (version 6.0). The abundance of ammonia-oxidizing bacteria, nitrite-oxidizing bacteria, and phosphorus accumulating organisms as percentages of all bacteria (as area occupied by Probe-binding cells) was calculated from the images as the number of pixels with a positive signal from the specific probe and the EUB338 probe compared to the number of pixels with a positive signal from the EUB338 probe. The mean values of cells were calculated by examining at least 10 visual fields. The measurements were performed in triplicate for each probe.

\section{Results and discussion}

\section{Removal of COD}

Total COD is composed of colloidal, particulate, and soluble COD. Parts of the soluble COD were consumed by microbial assimilation, and others were used as a carbon source for nitrogen and phosphorus removal. Particulate 
and colloidal COD are retained by MBR, have a longer time to be degraded in the aeration tank, become part of activated sludge, and then are removed through the sludge discharge. Soluble microbial products (SMP) are main organic component of the effluent, but are also the main component of the effluent COD (Jarusutthirak and Amy 2007), which is a major cause of membrane fouling (Okamura et al. 2009).

Chemical oxygen demand removal efficiencies are shown in Fig. 2a. The results showed that COD concentrations of the ABR effluent fluctuated slightly, indicating that the ABR has a strong ability to adapt to changes in operating conditions. The improvement of ABR effluent quality simultaneously decreased the CAMBR effluent COD. The CAMBR run was stable with the average effluent COD of $24 \mathrm{mg} / \mathrm{L}$ and COD removal efficiency of $94 \%$.

The COD concentrations in different tanks are shown in Table 1, COD consumption significantly decreased along the CAMBR $(p<0.05)$, and the ABR consumed a large amount of COD with the COD removal efficiency of $73 \%$. COD removals in ABR occurred in two main ways: one way was the anaerobic microbial metabolism, and the other was the result of a higher percentage of COD being

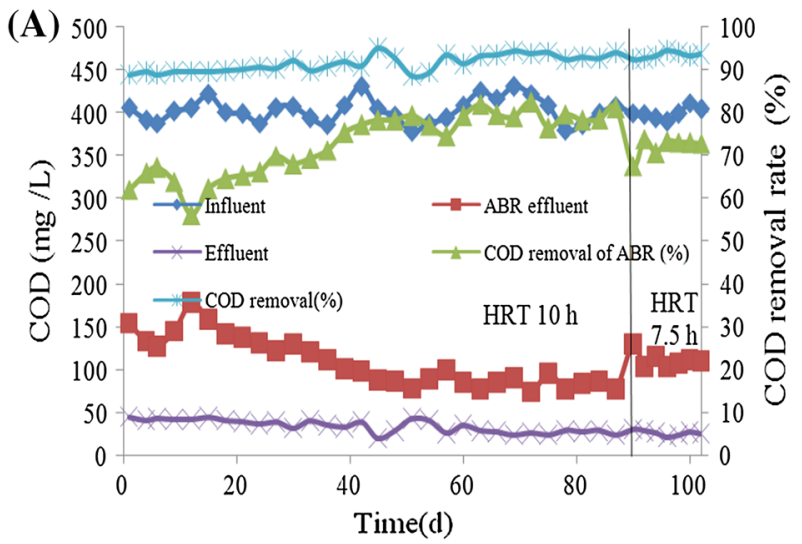

(C)

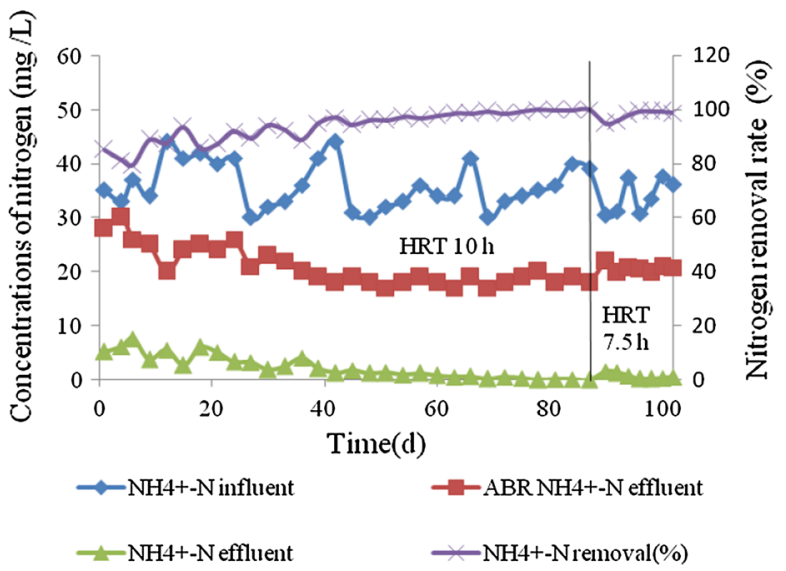

removed as carbon source of denitrification or phosphorus release. COD in the aerobic tank or the MBR were consumed by two main processes: aerobic metabolism and carbon source for denitrification.

Removal of nitrogen

Figure 2c presents $\mathrm{NH}_{4}{ }^{+}-\mathrm{N}$ removal efficiencies in the CAMBR. The ABR effluent $\mathrm{NH}_{4}{ }^{+}-\mathrm{N}$ concentration is relatively steady. Although the system effluent $\mathrm{NH}_{4}{ }^{+}-\mathrm{N}$ concentrations were increased, while the HRT changed on day 90 , the system effluent $\mathrm{NH}_{4}{ }^{+}-\mathrm{N}$ concentration gradually decreased after day 94 , indicating that the CAMBR run was stable, and the aerobic tank and the MBR pool had a good nitrification with average effluent $\mathrm{NH}_{4}{ }^{+}-\mathrm{N} 0.4 \mathrm{mg} / \mathrm{L}$ and removal rate of $99 \%$.

Total nitrogen removal efficiencies in the CAMBR are shown in Fig. 2d. On day 90, total nitrogen removal efficiency of the ABR decreased to $43 \%$, while TN removal efficiencies of aerobic tank and MBR were $31 \%$ with TN removal efficiency of $74 \%$ in the CAMBR. Because of the change of operating condition, denitrification in the ABR gradually improved as well as nitrification in aerobic tank

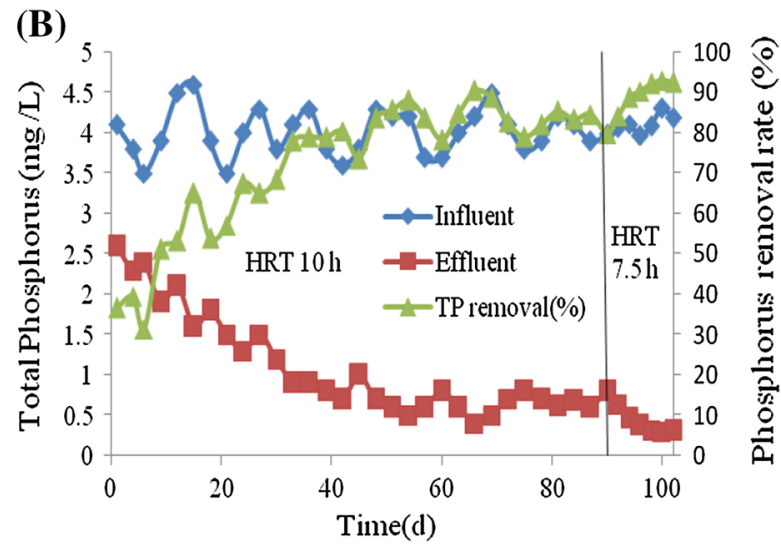

(D)

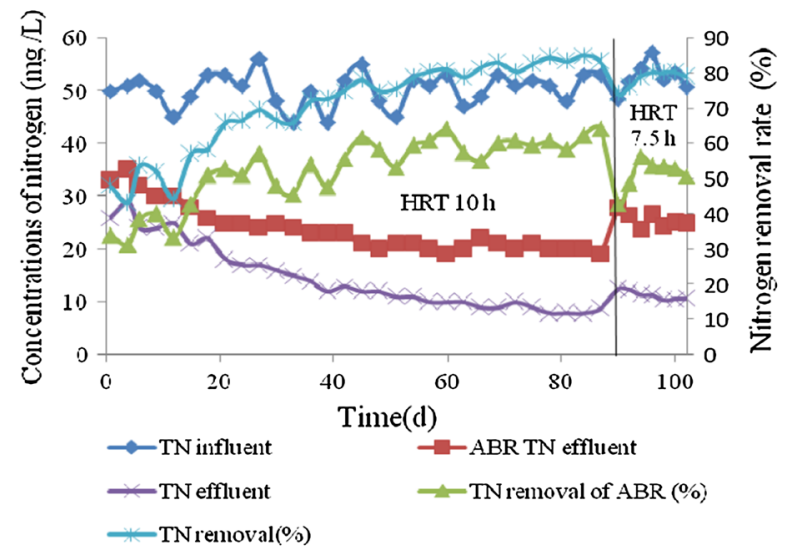

Fig. 2 COD (a), TP (b), $\mathrm{NH}_{4}{ }^{+}-\mathrm{N}(\mathbf{c})$ and TN (d) variations as well as removal efficiencies in the CAMBR 
Table 1 Variations of COD, $\mathrm{NH}_{4}{ }^{+}-\mathrm{N}, \mathrm{NO}_{3}{ }^{-}-\mathrm{N}, \mathrm{NO}_{2}{ }^{-}-\mathrm{N}$, TN, and TP concentration along the CAMBR

\begin{tabular}{lccccccc}
\hline & Influent & ABR-tank 1 & ABR-tank 2 & ABR-tank 3 & Aerobic tank & MBR tank & Effluent \\
\hline $\mathrm{COD}$ & $404 \pm 8$ & $282 \pm 7$ & $184 \pm 6$ & $109 \pm 5$ & $67 \pm 4$ & $44 \pm 3$ \\
$\mathrm{NH}_{4}{ }^{+}-\mathrm{N}$ & $36.1 \pm 1.82$ & $22.1 \pm 1.17$ & $23.6 \pm 1.21$ & $20.3 \pm 1.09$ & $5.7 \pm 0.24$ & $3.1 \pm 0.15$ & $0.4 \pm 0.02$ \\
$\mathrm{NO}_{3}{ }^{-}-\mathrm{N}$ & $0.35 \pm 0.2$ & $4.4 \pm 0.19$ & $0.4 \pm 0.02$ & $0 \pm 0$ & $6.8 \pm 0.35$ & $7.5 \pm 0.49$ & $6.7 \pm 0.34$ \\
$\mathrm{NO}_{2}{ }^{-}-\mathrm{N}$ & $0.1 \pm 0.01$ & $0.2 \pm 0.01$ & $0 \pm 0$ & $0 \pm 0$ & $0.3 \pm 0.02$ & $0.2 \pm 0.01$ & $0.1 \pm 0.01$ \\
$\mathrm{TN}$ & $50.7 \pm 2.44$ & $35.3 \pm 1.93$ & $29.4 \pm 1.56$ & $24.9 \pm 1.38$ & $16.1 \pm 0.87$ & $12.4 \pm 0.72$ & $10.6 \pm 0.55$ \\
$\mathrm{TP}$ & $4.19 \pm 0.02$ & $4.53 \pm 0.02$ & $14.93 \pm 0.74$ & $7.19 \pm 0.45$ & $1.06 \pm 0.08$ & $0.48 \pm 0.02$ & $0.31 \pm 0.02$ \\
\hline
\end{tabular}

Mean $\pm \mathrm{SD}(N=3)$

and MBR, stabilizing the effluent TN of the system. The average $\mathrm{TN}$ removal efficiency in the ABR was $52 \%$, while the CAMBR TN removal efficiency was $79 \%$ with effluent TN of $10.6 \mathrm{mg} / \mathrm{L}$ on day 102 . This suggests that the large fluctuations in operating condition should be avoided, and disturbance should be reduced in the environment for nitrifying bacteria and denitrifying bacteria group to ensure good nitrogen removal.

\section{Removal of phosphorus}

The CAMBR removal efficiencies of TP are shown in Fig. 2b. Phosphorus removal performance was gradually improved during the start-up. After day 40, effluent TP of the CAMBR was lower than $1 \mathrm{mg} / \mathrm{L}$. When the operating condition was changed on day $90, \mathrm{NO}_{\mathrm{x}}^{-}-\mathrm{N}$ in the $\mathrm{ABR}$ was not completely removed by denitrification and was as high as $0.4 \mathrm{mg} / \mathrm{L}$. Therefore, it is a priority for denitrification; thus, activities of phosphorus accumulating organisms are inhibited (Kuba et al. 1996), as they lead to insufficient phosphorus release in the ABR as well as phosphorus uptake in the aerobic tank and the MBR, resulting in relative low TP removal efficiency. However, denitrification in the ABR improved during the operation, and nitrate or nitrite was removed completely, and then, the phosphorus release and phosphorus uptake gradually stabilized. Finally, phosphorus release in the ABR and phosphorus uptake in both aerobic tank and the MBR gradually increased, with the effluent TP of $0.31 \mathrm{mg} / \mathrm{L}$, and the average removal efficiency of $92 \%$.

Analysis of methanation impact on denitrification

As denitrification competes with methanation for the common organic substrate as a carbon source, and denitrifying bacteria and methanogenic bacteria are two diverse microorganisms, denitrification and methanation are two relatively independent processes; therefore, they are difficult to occur simultaneously (Aguilera et al. 2005). Moreover, according to McCarty's (1966) yield algorithms, while carbon dioxide or nitrate used as electron acceptor and carbohydrates as electron donor, the growth rates of bacteria were $0.208 \mathrm{~g} \mathrm{VSS} / \mathrm{g}$ and $0.534 \mathrm{~g} \mathrm{VSS} / \mathrm{g}$, respectively. Furthermore, when carbon dioxide was used as the electron acceptor, the generation growth time of bacteria was 16 times slower than that of nitrate as electron acceptor, indicating that it is conducive to denitrification in the competitive process of denitrification and methanogenesis. Thus, organic carbon will be a priority for denitrifying bacteria to produce nitrogen. Ruiz et al. (2006) also found that when nitrate and organic carbon both exist, it is mainly resulted in denitrification and did not produce methane. EI-Mahrouki and Watson-Craik (2004) found that methanation can occur after the end of denitrification, because denitrification produces intermediates, and $\mathrm{NO}_{\mathrm{x}}^{-}-\mathrm{N}$ has a certain inhibition on methanogenic bacteria. Therefore, denitrification still performed well and was not affected by methanation, even though the carbon source was insufficient.

\section{Mechanism of nitrogen removal in the CAMBR}

Table 1 shows variations of $\mathrm{NH}_{4}^{+}-\mathrm{N}, \mathrm{TN}, \mathrm{NO}_{3}^{-} \mathrm{N}$, and $\mathrm{NO}_{2}{ }^{-}-\mathrm{N}$ along the CAMBR. The nitrogen removal mechanism can be revealed by determining the concentrations of $\mathrm{NH}_{4}{ }^{+}-\mathrm{N}, \mathrm{NO}_{\mathrm{x}}^{-} \mathrm{N}$, and $\mathrm{TN}$ in every compartment of the CAMBR. The results showed that, as the nitrification liquor recycled, $\mathrm{NH}_{4}{ }^{+}-\mathrm{N}$ concentration significantly decreased in compartment 1 due to dilution $(p<0.05)$. However, ammonia concentration in compartment 2 was higher than in compartment 1 , which may be due to $\mathrm{NH}_{4}{ }^{+}-\mathrm{N}$ which derived from the degradation of nitrogencontaining organic compounds by anaerobic microorganisms which were more than needed for microorganisms' growth. Subsequently, ammonia concentration decreased in compartment 3, which may be related to the use of ammonia as a nitrogen source for synthesis of amino acid through anaerobic microbial assimilation and dilution. From the analysis of the CAMBR, it can be seen that the reason why the system used two aerobic nitrification processes is that the ammonia which is not removed in the aerobic tank can be further removed in the MBR. Ammonia concentration decreased sharply in the aerobic tank, indicating that the aerobic nitrifying bacteria in the aerobic tank have a strong capacity of nitrification. The ABR effluent $\mathrm{NO}_{\mathrm{x}}^{-}-\mathrm{N}$ concentration dropped significantly $(p<0.05)$, revealing that denitrifying bacteria in the ABR 
also had a strong denitrification capacity. The concentration of $\mathrm{NO}_{\mathrm{x}}^{-}-\mathrm{N}$ in the MBR increased $0.6 \mathrm{mg} / \mathrm{L}$ above that of the effluent in the aerobic tank, but was about $1.9 \mathrm{mg} / \mathrm{L}$ lower than the $\mathrm{NH}_{4}{ }^{+}-\mathrm{N}$ reduction $(2.5 \mathrm{mg} / \mathrm{L})$, showing that denitrification occurred in the MBR; the effluent $\mathrm{NO}_{\mathrm{x}}^{-}-\mathrm{N}$ concentration was lower than $\mathrm{NO}_{\mathrm{x}}^{-}-\mathrm{N}$ concentration in the MBR, indicating the existence of denitrification in the membrane module, thereby enhancing the overall nitrogen removal in the CAMBR. This may be due to an external aerobic zone and an internal anaerobic zone in the membrane module caused by the DO concentration gradients; thus, part of the $\mathrm{NO}_{\mathrm{x}}^{-}-\mathrm{N}$ components were removed by denitrification in the anaerobic zone. Nitrate or nitrite were not detected in the ABR effluent, and the CAMBR effluent $\mathrm{NH}_{4}{ }^{+}-\mathrm{N}$ concentrations were as low as $0.4 \mathrm{mg} / \mathrm{L}$, indicating that a good balance between nitrification and denitrification was obtained in the CAMBR. This is mainly due to the long sludge retention time exceeding the generation time of ammonia-oxidizing bacteria and nitrite-oxidizing bacteria, it will not affect nitrification. Moreover, the microenvironment of low organic loading and high dissolved oxygen was conducive to the growth and accumulation of autotrophic nitrifying bacteria (Baikun et al. 2007; Chen and LaPara 2008) in the MBR. In addition, the efficient microorganism retention of the membrane ensures that autotrophic nitrifying bacteria with a long generation time were retained in the process, which improved the overall nitrification. Furthermore, sufficient carbon source ensured adequate denitrification, and $\mathrm{NO}_{\mathrm{x}}^{-}-\mathrm{N}$ can be fully converted to nitrogen gas through denitrification. While the MBR mixed liquor introduced to the third compartment of the $\mathrm{ABR}, \mathrm{NO}_{\mathrm{x}}^{-}-\mathrm{N}$ was further utilized by denitrifying polyphosphate accumulating organisms. Biological denitrification mainly occurred in the ABR, but the TN concentration in the aerobic tank reduced, indicating the existence of simultaneous nitrification and denitrification here, which may be relevant to high MLSS ( $8 \mathrm{~g} / \mathrm{L}$ ) uneven aeration (Peng and Ge 2011). Total nitrogen concentration in aerobic tank and TN removal rate of the aerobic tank was $16.1 \mathrm{mg} / \mathrm{L}$ and $17 \%$, respectively. The MBR also improved the level of simultaneous nitrification and denitrification, which results in a further $\mathrm{TN}$ removal.

\section{Mechanism of phosphorus removal in the CAMBR}

The DO in the aerobic tank and in the MBR was controlled at $3 \mathrm{mg} / \mathrm{L}$ that was desired to achieve better TP removal (Meng et al. 2012). The variations of TP concentration along the CAMBR are shown in Table 1. The recycled nitrification liquor was mixed with the raw water in compartment 1 first, and then, denitrification completed. Phosphorus release occurred in compartment 1 , which may be due to nitrate and nitrite were consumed to sufficiently low levels in the compartment 1 . The amount of released phosphorus increased in compartment 2, with TP concentration of $14.93 \mathrm{mg} / \mathrm{L}$. While as the MBR mixed liquor was introduced to the third compartment of the ABR, denitrifying polyphosphate accumulating organisms utilized nitrates to further take up phosphorus, and TP concentration significantly decreased to $7.19 \mathrm{mg} / \mathrm{L}(p<0.05)$. Total phosphorus concentration in the aerobic tank was significantly decreased to $1.06 \mathrm{mg} / \mathrm{L}(p<0.05)$, indicating that the P-uptake activity of phosphorus accumulating organisms was effective. Total phosphorus concentration decreased $0.48 \mathrm{mg} / \mathrm{L}$ in the MBR and was ultimately removed through sludge discharge (Lesjean et al. 2002), further strengthening the role of P-uptake. It was mainly due to the full microorganism retention of the membrane that increased the total amount of phosphorus accumulating organisms. The CAMBR effluent TP concentration was $0.17 \mathrm{mg} / \mathrm{L}$ lower than the TP concentration in the MBR, and the TP removal by membrane retention was $4 \%$, enhanced TP removal of the CAMBR.

\section{Analysis of fluorescence in situ hybridization}

In recent years, FISH technology has been successfully used in the study of ammonia-oxidizing bacteria, nitriteoxidizing bacteria, and phosphorus accumulating organisms and has revealed many new physiological characteristics and functions of these bacteria. This has helped our further understanding of the principles of biological nutrient removal in wastewater, thus improving the performance of the existing systems and the development of new technology. To assess the composition of the sludge in the steady state, FISH was performed with the 16S rRNA targeting oligonucleotide probes NSO190, Nit3 and EUB338. NSO190 targeted ammonia-oxidizing bacteria, while Nit3 targeted nitrite-oxidizing bacteria, and PAOMIX targeted phosphorus accumulating organisms, respectively, EUB338 targeted the eubacteria cluster (Fig. 3). The results of the proportion of ammonia-oxidizing bacteria, nitrite-oxidizing bacteria, and phosphorus accumulating organisms to all eubacteria in the CAMBR are shown in Fig. 4. The three detected bacteria in each compartment had small fluctuations in the proportion of eubacteria, in which the proportion of ammonia-oxidizing bacteria and nitrite-oxidizing bacteria varied from 17 to $23 \%$ and from 6 to $11 \%$, respectively, with the smallest fluctuations in the proportion of phosphorus accumulating organisms from 19 to $22 \%$. In addition, the percentages of ammonia-oxidizing bacteria and nitrite-oxidizing bacteria in compartment 3 were lowest of all, while the largest was in the MBR, which may be due to the fact that the larger granular sludge in the bottom of the ABR do not participate in the sludge recycling, and the microbial populations in 

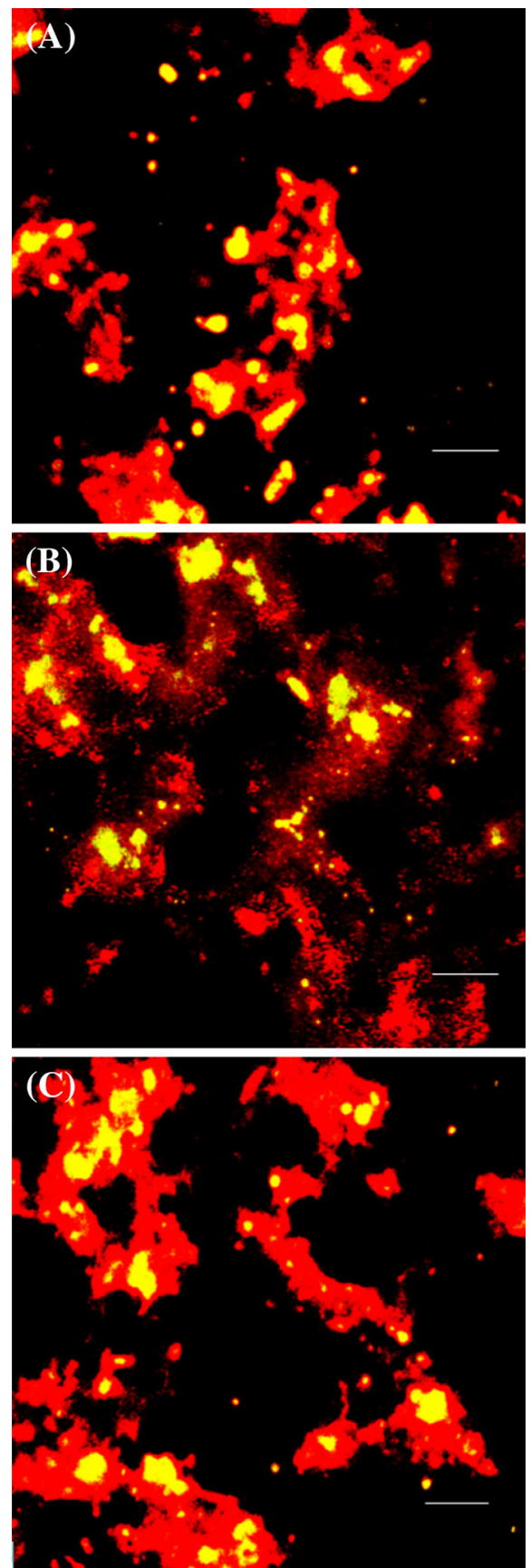

Fig. 3 Fluorescence in situ hybridization micrographs of sludge in MBR hybridized with FITC-labeled NSO190, Nit3, PAOMIX and CY3-labeled EUB338. NSO190 targeted ammonia-oxidizing bacteria (a), Nit3 targeted nitrite-oxidizing bacteria (b), and PAOMIX targeted phosphorus accumulating organisms (c). $B a r=100 \mu \mathrm{m}$

the larger granular sludge of the ABR were different from the microbial populations in the aerobic sludge. When the aerobic sludge mixed with the larger granular sludge in the $\mathrm{ABR}$, the percentages of ammonia-oxidizing bacteria and nitrite-oxidizing bacteria decreased slightly. Overall, the proportions of the three kinds of bacteria in the CAMBR did not change significantly due to the quick sludge

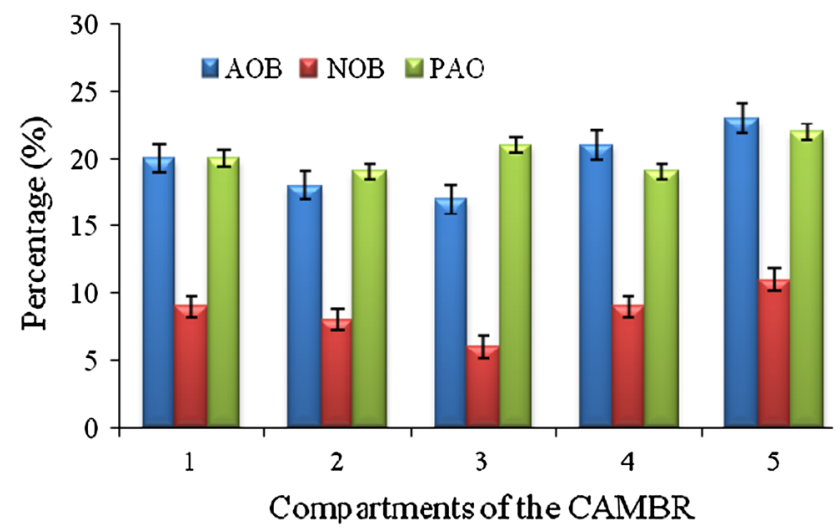

Fig. 4 Bacterial composition of the activated sludge in each compartment of the CAMBR. AOB, ammonia-oxidizing bacteria; NOB, nitriteoxidizing bacteria; and PAO, phosphorus accumulating organisms

recycling. The three types of microorganisms were enriched in the system and the sum of the percentages of the three types of bacteria was high (Koch et al. 2001; Yang et al. 2010). This may be the underlying reason why the CAMBR is efficient for simultaneous nitrogen and phosphorus removal.

\section{Conclusion}

When the nitrification liquor was recycled to compartment 1 with the HRT of $7.5 \mathrm{~h}$ at the recycling ratio of $200 \%$ and the DO at $3 \mathrm{mg} / \mathrm{L}$ under the average MLSS concentration about $8,000 \mathrm{mg} / \mathrm{L}$ in both the aerobic tank and the MBR, simultaneous nitrification and denitrification enhanced nitrogen removal in the CAMBR. The ammonia removal rate was about $99 \%$ with TN removal rate of $79 \%$. The CAMBR effluent $\mathrm{NH}_{4}{ }^{+}-\mathrm{N}$ and $\mathrm{TN}$ concentrations were $0.4 \mathrm{mg} / \mathrm{L}$ and $10.6 \mathrm{mg} / \mathrm{L}$, respectively. Taking characteristics of anaerobic phosphorus release, denitrifying polyphosphate accumulating organisms P-uptake and further aerobic phosphorus uptake of phosphorus accumulating organisms together, the total phosphorus ultimately removed through sludge discharge with the CAMBR effluent TP of $0.31 \mathrm{mg} / \mathrm{L}$. The membrane retention removed TP $0.17 \mathrm{mg} / \mathrm{L}$, enhanced biological phosphorus removal with the CAMBR TP removal of $92 \%$. The MBR enhanced $\mathrm{NH}_{4}{ }^{+}-\mathrm{N}, \mathrm{TN}$ and TP removal rates of 14,10 and $17 \%$, respectively. The CAMBR achieved stable and efficient nutrient removal performance with good quality effluent and can be suitably used to satisfy the demand in the lake Taihu area. The results of FISH analysis have shown that three types of detected bacteria in each compartment had small fluctuations in the proportion of eubacteria. The three types of enriched microorganisms in the system appeared to be the underlying reason of the CAMBR is efficient for nutrient removal. 
Acknowledgments The author would like to thank Dr. Bill McCann, Dr. Hutchinson and Dr. Xiaohua Zhang for a comprehensive review of this manuscript and the anonymous reviewers for useful suggestions. This research was financially supported by the key project of Natural Science Research (12KJA610002) and the project of scientific Innovation Research (CXZZ12_0857) to Jiangsu universities. We gratefully acknowledge Jiangsu Key Laboratory of Environmental Science and Engineering for technical assistance.

Conflict of interest The authors declare that they have no conflict of interest.

\section{References}

Aguilera J, Petit T, De Winde JH, Pronk JT (2005) Physiological and genome-wide transcriptional responses of Saccharomyces cerevisiae to high carbon dioxide concentrations. FEMS Yeast Res 5:579-593

Amann RI (1995) In situ identification of micro-organisms by whole cell hybridization with rRNA-targeted nucleic acid probes. Mol Microb Ecol Manual:1-15

APHA-AWWA-WEF (2005) Standard methods for the examination of Water and wastewater, 21st edn. American Public Health Association/American Water Works Association/Water Environment Federation, Washington

Baikun L, Shannon I, Katherine B (2007) The variation of nitrifying bacterial population sizes in a sequencing batch reactor (SBR) treating low, mid, high concentrated synthetic wastewater. J Environ Eng Sci 6:651-663

Chen RD, LaPara TM (2008) Enrichment of dense nitrifying bacterial communities in membrane-coupled bioreactors. Process Biochem 43:33-41

Chu LB, Zhang XW, Yang FL, Li Xh (2006) Treatment of domestic wastewater by using a micro aerobic membrane bioreactor. Desalination 189:181-192

Chuai X, Chen X, Yang L, Zeng J, Miao A, Zhao H (2012) Effects of climatic changes and anthropogenic activities on lake eutrophication in different ecoregions. Int J Environ Sci Technol 9:503-514

Coskuner G, Ballinger SJ, Davenport RJ, Pickering RL, Solera R, Head IM, Curtis TP (2005) Agreement between theory and measurement in quantification of ammonia-oxidizing bacteria. App Environ Microbiol 71:6325-6334

Crocetti GR, Hugenholtz P, Bond PL, Schuler A, Keller J, Jenkins D, Blackall LL (2000) Identification of polyphosphate-accumulating organisms and design of $16 \mathrm{~S}$ rRNA-directed probes for their detection and quantitation. Appl Environ Microbiol 66:1175-1182

Egli K, Langer C, Siegrist HR, Zehnder AJB, Wagner M, Meer JR (2003) Community analysis of ammonia and nitrite oxidizers during start-up of nitridation reactors. Appl Environ Microbiol 69:3213-3222

EI-Mahrouki IML, Watson-Craik IA (2004) The effects of nitrate and nitrate-supplemented leachate addition on methanogenesis from municipal solid waste. J Chem Technol Biotechnol 79:842-850

Gong Z, Liu S, Yang F, Bao H, Furukawa K (2008) Characterization of functional microbial community in a membrane-aerated biofilm reactor operated for completely autotrophic nitrogen removal. Bioresour Technol 99:2749-2756

Hong Q, Sun Z, Chen L, Liu R, Shen Z (2012) Small-scale watershed extended method for non-point source pollution estimation in part of the three gorges reservoir region. Int J Environ Sci Technol 9:595-604

Jarusutthirak C, Amy G (2007) Understanding soluble microbial products (SMP) as a component of effluent organic matter (EfOM). Water Res 41:2787-2793
Kim HG, Jang HN, Kim HM, Lee DS, Eusebio RC, Kim HS, Chung TH (2010) Enhancing nutrient removal efficiency by changing the internal recycling ratio and position in a pilot-scale MBR process. Desalination 262:50-56

Koch G, Kuhni M, Siegrist H (2001) Calibration and validation of an ASM3-based steady-state model for activated sludge systems. part 1. Prediction of nitrogen removal and sludge production. Water Res 35:2235-2245

Kuba T, Van Loosdrecht MCM, Heunen JJ (1996) Phosphorus and nitrogen removal with minimal COD requirement by integration of denitrifying dephosphatation and nitrification in a two-sludge system. Water Res 30:1702-1710

Lesjean B, Gnirss R, Adam C (2002) Process configurations adapted to membrane bioreactors for enhanced biological phosphorous and nitrogen removal. Desalination 149:217-224

McCarty PL (1966) Kinetics of waste assimilation in anaerobic treatment. In developments in industrial microbial sciences. American Institute of Biological Sciences, Washington

Meng FG, Zhou ZB, Li L, Li RY, Jia XS, Li SY (2012) A novel nearly plug-flow membrane bioreactor for enhanced biological nutrient removal. AIChE J. doi:10.1002/aic.13799

Monclús H, Sipma J, Ferrero G, Rodaa IR, Comas J (2010) Biological nutrient removal in an MBR treating municipal wastewater with special focus on biological phosphorus removal. Bioresour Technol 101:3984-3991

Okamura D, Mori Y, Hashimoto T, Hori K (2009) Identification of biofoulant of membrane bioreactors in soluble microbial products. Water Res 43:4356-4362

Peng YZ, Ge SJ (2011) Enhanced nutrient removal in three types of step feeding process from municipal wastewater. Bioresour Technol 102:6405-6413

Röske I, Röske K, Uhlmann D (1998) Gradients in the taxonomic composition of different microbial systems: comparison between biofilms for advanced waste treatment and lake sediments. Water Sci Technol 37:159-166

Ruiz G, Jeison D, Rubilar O, Ciudad G, Chamy R (2006) Nitrification-denitrification via nitrite accumulation for nitrogen removal from wastewaters. Bioresour Technol 97:330-335

Satoshi O, Hisashi S, Yoshimasa W (1999) In situ analysis of nitrifying biofilms as determined by in situ hybridization and the use of microelectrodes. Appl Environ Microbiol 65:3182-3191

Strosnider WH, Winfrey BK, Nairn RW (2011) Biochemical oxygen demand and nutrient processing in a novel multi-stage raw municipal wastewater and acid mine drainage passive cotreatment system. Water Res 45:1079-1086

Su YY, Mennerich A, Urban B (2011) Municipal wastewater treatment and biomass accumulation with a wastewater-born and settleable algal-bacterial culture. Water Res 45:3351-3358

Suwa Y, Suzuki T, Toyohara H, Yamagishi T, Urushigawa Y (1992) Single-stage, single sludge nitrogen removal by activated sludge process with cross-flow filtration. Water Res 26:1149-1157

Tian P, Zhao G, Li J, Gao J, Zhang Z (2012) Integration of monthly water balance modeling and nutrient load estimation in an agricultural catchment. Int J Environ Sci Technol 9:163-172

Uan DK, Yeom IT, Arulazhagan P, Rajesh Banu J (2013) Effects of sludge pretreatment on sludge reduction in a lab-scale anaerobic/ anoxic/oxic system treating domestic wastewater. Int J Environ Sci Technol 10:495-502

Yamagishi T, Leite J, Ueda S, Yamaguchi F, Suwa Y (2001) Simultaneous removal of phenol and ammonia by an activated sludge process with cross-flow filtration. Water Res 35: 3089-3096

Yang S, Yang FL, Fu ZM, Wang T, Lei R (2010) Simultaneous nitrogen and phosphorus removal by a novel sequencing batch moving bed membrane bioreactor for wastewater treatment. J Hazard Mater 175:551-557 